\title{
USING THINK-PAIR-SQUARE-SHARE STRATEGY TO IMPROVE STUDENTS' SPEAKING ABILITY FOR INDONESIAN SENIOR HIGH SCHOOL STUDENTS
}

\author{
Devi Rufiana \\ Mulyadi \\ English Education Study Program \\ Department of Languages and Arts \\ Faculty of Teachers Training and Education of Bengkulu University \\ Bengkulu City, Indonesia \\ E-mail:missdevi96@gmail.com \\ E-mail:mulyadi@unib.ac.id
}

\begin{abstract}
The objective of the research was to determine how the Think-Pair-Square-Share (TPSS) Strategy can improve the frequency, duration and accuracy speaking students. The subject wasthe second year of Language class, consists of 19 students. The quantitative and qualitative data were applied to see the improvement of students' speaking ability and improvement of learning situations for the strategy applied. The instruments used to gather the data werea students' speaking ability test and observation sheet. Based on the results of the test conducted at the end of the study and analysis of observation sheets, it could be said that the speech and behavior of students during the learning process had increased. The students' speaking frequency, duration and accuracy orderly increasedfrom $31 \%, 47 \%$, and $37 \%$ at baseline to $79 \%, 84 \%$ and $79 \%$ at the end of the study. Results showed that the number of students at the end of the research had achieved success indicator. The students also showed motivation, interest, participation, and enthusiasm better for the learning process.
\end{abstract}

Key words: Speaking Ability, Think-Pair-Square-Share Strategy

Abstrak: Tujuan dari penelitian ini adalah untuk menentukan bagaimana Think-Pair-SquareShare (TPSS) Strategi dapat meningkatkan frekuensi, durasi dan akurasi berbicara siswa. Subjek penelitianiniadalah tahun kedua kelas Bahasa, terdiridari 19 siswa. Data kuantitatif dan kualitatif diterapkan untuk melihat peningkatan kemampuan berbicara siswa dan peningkatan situasi belajar terhadap strategi yang diterapkan. Instrumen yang digunakan untuk mengumpulkan data adalah tes kemampuan berbicara siswa dan lembar observasi. Berdasarkan hasil uji yang dilakukan pada akhir penelitian dan analisis lembar observasi, dapat disimpulkan bahwa ucapan dan perilaku siswa selama proses pembelajaran meningkat. Frekuensi, durasi dan akurasi berbicarasiswateratur meningkat dari 31\%, 47\%, dan 37\% di awal menjadi 79\%, 84\% dan $79 \%$ di akhir penelitian. Hasil penelitianini menunjukkan bahwa jumlah siswa pada akhir penelitian telah mencapai indikator keberhasilan. Siswa juga menunjukkan motivasi, minat, partisipasi, dan antusiasme yang lebih baik dalam proses pembelajaran.

Kata kunci:KemampuanBerbicara, Think-Pair-Square-Share Strategy 


\section{INTRODUCTION}

Speaking is a crucial part in language teaching and learning, and the goal of teaching speaking is that should be based on improving students' communicative ability. By this way, students can express themselves and learn how to follow the social and cultural rules appropriately. This reality makes teachers and parents think that speaking ability should be mastered by their students or children.

These facts have the teacher to concern in teaching speaking in order to develop the students' communicative ability. Consequently, teacher should be able to create a good strategy in one method in teaching English more interest and fun. Nunan (2003) describes a language teaching method is a single set of procedures which teachers are to follow in the classroom. Method is needed in order to motivate students to learn and to help students to understand about the materials they learn. A method will be a bridge between teacher and students in processing the material.

Cooperative learning is introduced as a method that requires students to work together to improve their own learning. In cooperative learning, students may have interaction each other over subject matter which make easier to students collaborate through team working, discussing, and sharing in learning process. Kagan (1992) states that cooperative learning is a successful teaching strategy in which small teams, each with students of different levels of ability use a variety of learning activities to improve their understanding of a subject.

Cooperative learning delivers many strategies in its contribution in teaching and learning. As cited in Kagan (1992), Frank Lyman has developed a simple but very powerful thinking skills structure which is as one of cooperative learning technique, Think-Pair-Square-Share or TPSS. Think-Pair-Square-Share is the development of Think-Pair-Share strategy which has three steps, but TPSS is a strategy that deals with four steps; think the subject matter, discuss in pair, communicate again in square and share it to the whole class.

Think-Pair-Square-Share is involving four steps cooperative structure. During the first step individuals think silently about a question posed by the teacher/instructor. Individuals pair up during the second step and exchange thoughts in square for the third step. In the fourth step, the square shares their responses with other square, other teams, or the entire group. Kagan (1992) describes in TPSS after a problem is posed, students think alone about the question for specific amount time, then form pairs to discuss the question with someone in the class, usually teammates, for the square is a team discussion (so, the students get more time to think), and last students called upon to share the answer with the class as a whole.

Think-Pair-Square-Share is helpful because it structures the discussion. TPSS is believed as a discussion strategy that brings students to be cooperating each other. Nunan (2003) says that pair work or group work activities can be used to increase the amount of time that learners get to speak during lessons. This statement is appropriate to Think-Pair-Square-Share strategy in which students work in a small group and gets to speak.

On the other hand, TPSS can be used in the four skills; listening, speaking, speaking and writing. Critical thinking, discussion and cooperation are the main point of Think-PairSquare-Share technique. In speaking, those points are needed; where critical thinking is the underlayment speaking that will be back up students in find ideas; discussion helps students in exploring ideas; and to get it all of those goals, cooperative each other will strengthen the result. Thus TPSS is believed as a technique that requires and appropriate in supporting teaching and learning process.

There are some findings that related to improve students' speaking ability by using Think-Pair-Square-Share.First is Isnaini (2011), with entitled 'Improving the SpeakingAbility of the Tenth Graders of SMK Negeri 1 Singosari Malang through Think-Pair-Square Strategy'. The finding of the research indicated that ThinkPair-Square strategy was successful in improving students' speakingability. The improvement could be seen from the increase of the number of 
students who achieved the minimum passing grade $22.5 \%$ in preliminary study, $67.7 \%$ in Cycle 1, and $90.3 \%$ in Cycle 2.

Second is Abdul Wafi (2011), with entitled 'Using the Think-Pair-Share Strategy to Increase Students' Active Involvement and toImprove Students' Speaking Ability at Islamic the University of Malang'. This study was designed to increase students' active involvement and toimprove their speaking ability using the ThinkPair-Share Strategy at Islamic University of Malang. The increase could be seen from the number of students who were categorized as actively involved from only 7 students (29\%) in the preliminary study to 20 students (78\%) of 26 .

Both of these studies have related to the research variable. These findings studies show that Think-Pair-Square-Share is an effective way to improve students' speaking ability. Considering the succesfulness of those previous study, the resercher is willing to conduct a research in improving the students speaking ability by using the same strategy which is ThinkPair-Square-Share at XI Language class of SMAN 4 Bengkulu. Both of studies will be hint to the result later.

The researcher had done teaching experience at XI of Language class in SMAN 4 Bengkulu, the problem frequently found that the students' speaking skill are low. Even though the Language class is a class that concerns to language subjects, such as English, not all of the students have good

\section{METHODOLOGY}

\section{Participants and contexts}

The setting of this research was the students of XI Language class of SMAN 4 Bengkulu in academic year 2012/2013. The number of the students were 19 consists of 11 females and 8 males. The researcher chose this class as the subject of the research because it is a language class which is language learning is concerned to be prominent than others subjects. Beside, the students' speaking ability was still low where $18 \%$ of them didn't achieve the minimum standard of passing grade 68 .

1 speaking. They got difficult in delivered their speech. This problem was seemed based on the researcher's observation in that class, when the teacher gave the students speaking task (expressing), the students were just silent, spent too much time to think of and how to start to speak. When the teacher gave speaking test, the students would ask to make writing at least 2 pages of the topic given and then memorize it. They had no chance to speak freely in the class. Because in speaking class, again, they just wrote and memorized it. Beside, based on the informal interview to the students, most of them said that they were afraid to take part in the conversation or gave an argument in speaking. They were still shy and afraid of making mistakes in speaking. It was proven by no more than 3 of 19 students who raised hand to speak. Further, XI Language class has only $20 \%$ of students who got highest score in speaking.

Based on the problems above, the research question was formulated as follow:How can Think-Pair-Square-Share strategy improve the students' speaking ability at XI Language class of SMAN 4 Bengkulu?This research question was elaborated into following specific questions:How does Think-Pair-Square-Share strategy improve the students' frequency in speaking?How does Think-Pair-Square-Share strategy improve the students' duration in speaking?

\section{Design and procedures}

The design of this research was classroom action research because there were several identified problems that need to be solved with the aims are for improvement and involvement. Moreover, Watts in Ferrance (2000) stated that action research is a process in which participants examine their own educational practice systematically and carefully, using the techniques of research with the intent that the research will inform and change his or her practices in the future.

The researcher designed a speaking test to the students of XI Language class of SMAN 4 Bengkulu. The types of test in this research are 
test before cycle (pre test) and test after cycle (post test). Test before cycle was given to the students before the researcher applied the strategy. It was used to support the baseline data of this research. And test after cycle was given to the students after the researcher applied the strategy. Both pre and post test was in oral form where the students were asked to speak in front of the class about their daily activities at least 30 words individually. It helped the researcher to see the improvement of ability of students in speaking. The test was made based on the syllabus and the school curriculum.

Action research was done through repeated cycles in action research. One cycle of Classroom Action Research consist of Plan, Action, Observation and Reflection. Procedures of this research as follow;

1. Planning, in planning activities, the researcher prepared lesson plans for teaching speaking ability by using Think-Pair-Square-Share technique. The lesson plans contained the materials based on the syllabus that the school used. The lesson plans were arranged for 3 meetings.

2. Acting, in action steps contained the steps in teaching speaking ability by using Think-Pair-Square-Share for each meeting in cycle 1 based on lesson plan and review of ThinkPair-Square-Share in chapter II.

3. Observating, in observation step used observation checklist and fieldnotes. By the instruments, both researcher and collaborator together observed the students' activities during learning process.

4. Reflecting, the step was done to measure the successfulness of ThinkPair-Square-Share technique. The data gathered during and after the cycle was compared to the indicator of success. It was been the reflection or guide decide whether or not the research continue to the next cycle. If the indicator of success had achieved then the cycle would be stopped.

\section{Research instruments and data analysis}

The instruments were students' speaking test and observation checklist and Fieldnotesthat contained the information about how students learn speaking in class and their response about Think Pair Square Share strategy in their speaking class. Both test and observation and fieldnotes were made to gather the data.

The researcher designed a speaking test to the students of XI Language class of SMAN 4 Bengkulu. The types of test in this research are test before cycle (pre test) and test after cycle (post test). Test before cycle was given to the students before the researcher applied the strategy. It was used to support the baseline data of this research. And test after cycle was given to the students after the researcher applied the strategy. Both pre and post test was in oral form where the students were asked to speak in front of the class about their daily activities at least 30 words individually. It helped the researcher to see the improvement of ability of students in speaking. The test was made based on the syllabus and the school curriculum.

This instrument contained the information about how students learn speaking in class and their response about Think Pair Square Share strategy in their speaking class. Both observation and fieldnotes was made in one checklist form. In these instruments, the researcher collaborated with the English teacher as collaborator/coresearcher of this research. The collaborator helped the researcher in observing and assessing the learning process based on learning situations in the classroom.

After gathering the data, the researcher analyzed the data. The data analysis was taken from data collection, quantitative and qualitative. In the process of, the researcher cooperated with the collaborator (teacher). And to analyze the data, the researcher used formulas. The formula below was used to find $\mathbf{P}$ (students' percentages of speaking ability), where $\mathbf{f}$ as the total of students who active in speaking criteria (each frequency, duration and accuracy) and divided to $\mathbf{N}$ (the total number of students 21), then timed to $100 \%$. 
Since speaking is hard to mark, the researcher used scoring criteria for the categories of the

learners speak, (Handayani: 2010) as follow:

Table 2 Scoring criteria

\begin{tabular}{||l|l|l|l||l|l|}
\hline \multicolumn{2}{|c|}{$\begin{array}{c}\text { Frequency per class } \\
\text { meeting }\end{array}$} & \multicolumn{2}{c||}{$\begin{array}{c}\text { Quantity of words per } \\
\text { students speak/duration }\end{array}$} & \multicolumn{2}{c|}{$\begin{array}{c}\text { Accuracy per students } \\
\text { speak }\end{array}$} \\
\hline OFTEN & $\begin{array}{l}\text { More than } \\
3 \text { times }\end{array}$ & LONG & $\begin{array}{l}\text { More than } 31 \\
\text { words }\end{array}$ & $\begin{array}{l}\text { VERY } \\
\text { GOOD }\end{array}$ & $0-1$ mistake \\
\hline SOMETIMES & $2-3$ times & MEDIUM & $21-30$ words & GOOD & $2-5$ mistakes \\
\hline SELDOM & $0-1$ time & SHORT & $0-20$ words & POOR & $\begin{array}{l}\text { more than } 6 \\
\text { mistakes }\end{array}$ \\
\hline
\end{tabular}

1) If the students are involved in the communication activities

2) $75 \%$ or more students are not reluctant any more to speak (the students' frequency is sometimes and often)

\section{FINDINGS AND DISCUSSION}

\section{Description of test before cycle}

Before conducting the research, the students were given a test. The test was given to get the basic score of students' speaking ability before applying the strategy.

From the result, it was concluded that the students' speaking ability was still low and the indicator did not achieve yet. Besides, from observation of the classroom situation done before doing the research, the researcher also found that the teaching and learning process was still monotone, where the activities were only let the students to wrote what they would speak and memorized it. Some of the students read their note in speaking test. Seemed, there was no variation both in the way of introducing the topic speaking and the types of task given to the students. As the result, the students had no interested in speaking.

In this case, a variation in teaching strategy was needed to be applied to improve the students' speaking ability and create a better teaching and learning process. Therefore, TPSS as the chosen strategy was expected to solve these problems.

\section{Description of cycles}

In the first cycle, there were some improvements of the students' speaking frequency, duration and accuracy in the implementation of Think-pair-
3) $75 \%$ or more students are speak in long and medium duration

4) $75 \%$ or more students are speaking at very good and good accuracy
Square-Share (TPSS) strategy in cycle 1. The result of the observation checklist and field notes showed that the students' attitude was not improved. There were still some things that should be improved in the teaching and learning process and also in applying the TPSS strategy to make it more effective in the class.

In the learning process, the students show their enthusiasm toward the new strategy. It was proven when the students discussed together in pair or square along the teaching and learning process, the students tried to involve in that process by listen and respond to their friend. They also tried to ask the teacher when got some words that was hard for them. But some weaknesses still found in the teaching and learning process. More than $50 \%$ of the students still spoke in Bahasa with another, making a joke to the friends. Some of them went out of classroom. The worse thing was they shouted when answer the questions from their friends in sharing the ideas. So the class was very noise.

Based on the observation explained, the indicator was not achieved yet. The students' attitude was also low. So then, the next cycle or cycle II was needed in order to solve the problems above. 
Before doing the action andusing Think-PairSquare-Share as the strategy to improve students' speaking ability in cycle 2 . The researcher and collaborator analyzed again the result of cycle 1 as the consideration in planning the lesson plan and preparing the material. Based on reflection discussed above, it seemed that the students' speaking frequency, duration and accuracy was still low. So then, the teacher should remake the lesson plan, the topic and the way in delivering the material. It was influence the students in learning speaking more enjoy and fun.

Like in cycle 1, the researcher and research collaborator prepared all the materials that the researcher needed in doing the research. The lesson plan was designed based on the syllabus and the school curriculum used. The material learned by XI Language class students were still conditional sentences. Besides, the observation checklist was designed to get the data needed effectively. But, in this cycle 2 , the researcher as the teacher made some improvement in implementing the strategy.

In cycle 1 the teacher had prepared material and only used the whiteboard in delivering the material. It made the students felt boring in learning speaking. So, the teacher tried to use a media to help students in speaking. It was picture as an alternative media in teaching speaking through applying Think-Pair-Square-Share strategy. It was measured to gain the students in developing the topic or ideas given. In the cycle 1 , the teacher got difficult in controlling the class. They were busy to chat among their friends. In order to overcome these problems, the teacher initiated to make a leader in every square. The leader had a duty in controlling and leading the square in order to keep discussing without shouting or disturbed the others.

There were some improvements in the implementation of Think-pair-Square-Share (TPSS) strategy in cycle 2. The result of the observation checklist and field notes showed that the students' attitude was improved. It meant that the alteration in the teaching and learning process and also in applying the TPSS strategy was good enough to make it more effective in the class.

In the learning process, the students show their enthusiasm toward the strategy. It was proven when the students discussed together in pair or square along the teaching and learning process, the students tried to involve in that process by listen and respond to their friend. They also tried to ask the teacher when got some words that was hard for them. Some weaknesses such as spoke in Bahasa with another, making a joke to the friends, and went outside of class were diminished. There was no more shouted to the others students during implementing the strategy.

Based on the result of cycle II, comparing with cycle 1 , it concluded that the percentages of students' frequency, duration and accuracy, and observation checklist were significantly increased. The indicator was also achieved. It is assumed that pictures make students faster to understand the instruction and knowing the idea to say. After discussing to the collaborator of research and the supervisor, the researcher stop to implements the action and would give post test as the end of this research.

The improvement of students' speaking ability In this stage, the improvement of the students speaking was showed. The first data were the baseline data that gotten from the test conducted before the implementation of the strategy. The test was given to see the improvement of the students' speaking ability of XI Language class before given the strategy.Moreover, the data was turned into a chart below: 
Chart 1.The improvement of pre test and post test

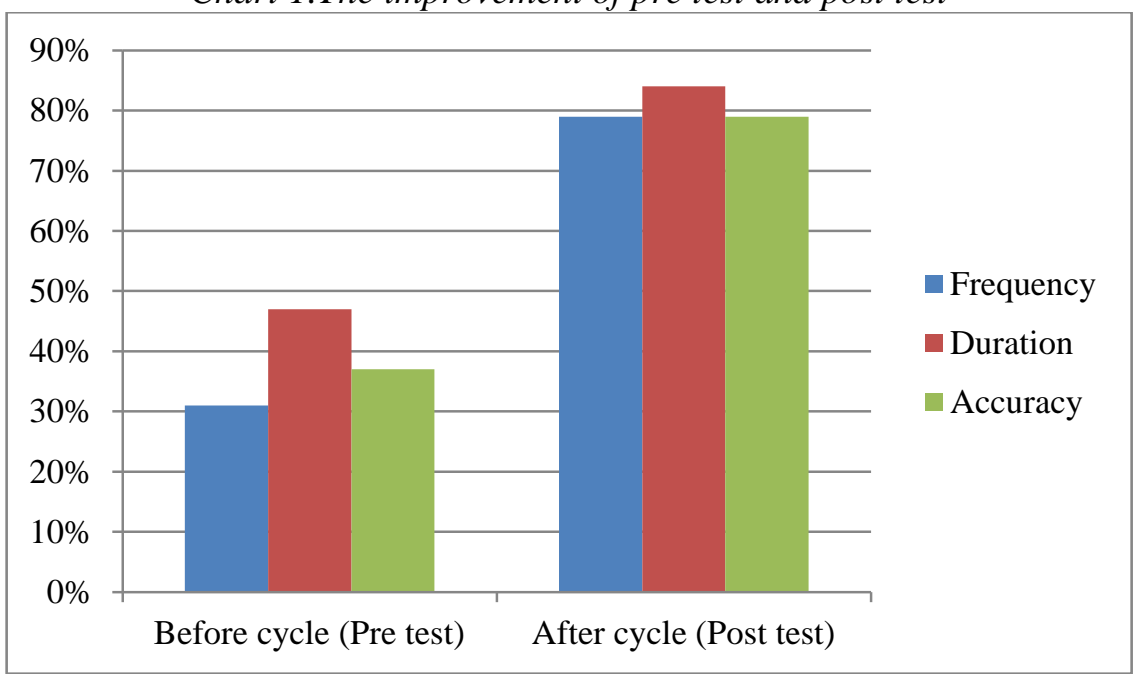

From the table, it can be said that the students' speaking ability was low with only $31 \%$ in ofte

and sometimes pars, $47 \%$ in long and medium parts, $37 \%$ in very good and good parts. Then, in the end of post test was increased with percentage $79 \%$ in often and sometimes pars, $84 \%$ in long and medium parts, $79 \%$ in very good and

\section{DISCUSSION}

Based on the result above, it showed that there was significance improvement of the students' speaking ability using Think-Pair-Square-Share strategy. It meant this strategy was success in improving the students' speaking ability, even though the result was not satisfied. The result also showed that the students' score from test before cycle compared with test after cycle was improved significantly. The observation checklist and field notes also showed that the students' attitude during the implementation of Think-Pair-SquareShare (TPSS) strategy was improved. The students cooperated in following the class and the activities. They were fully involved in the process of teaching and learning. They were more confident good parts. It was above the indicator of success set by the researcher which said that the use of Think-Pair-Square-Share strategy can be categorized as success. Based on the table above, it can be seen that there was significant improvement of the students' speaking ability. The data on the table showed that the students who passed the test improved in each stage; from the baseline data to final result

when they worked in pair, square and share step. More than half of class raised hand and no more reluctant in asking their miss understanding.In implementing the strategy, classroom action research (CAR) gave its contribution in teaching and learning process by using ThinkPair-Square-Share strategy at XI Language class of SMAN 4 Bengkulu. According to Gay (1990) the purpose of CAR is to solve the problem through the application of the scientific method. Cooperative learning as the method used in this research was success improving the students' problems and Think-PairSquare-Share was one of its strategies applied.

Based on the problems as presented in previous chapter, before the researcher 
implement Think-Pair-Square-Share (TPSS) strategy in teaching and learning process, the students' speaking ability was low. The observation and informal interview had been done in order to gather the students' problems. The problem frequently occurred was the students' reluctant. It meant the students were afraid of speaking class. Shyness and unconfident to spoke up made the students afraid of joint into conversation. If there was a student might join into a conversation, his/her duration in speaking was short, not more than 20 words. The students' accuracy was also poor. It was proven by the result that more than half of class made mistakes in 3 times and more. To overcome the problems, TPSS had been applied.

During the implementation of the strategy, students were asked to involve in the teaching and learning by sharing there ideas. By using this strategy, the teacher redefined the students' reluctant, duration and accuracy in speaking. The students were also stimulated to be more cooperative with the teacher while doing the individual, pair, square and share. The researcher who acted as the teacher guided, monitored, and made sure that the students followed the steps and procedures of Think-Pair-Square-Share (TPSS) Strategy.

The three categories were; first was frequency as how many time students want to speak, second was duration as how long or many words students use in speaking, and the last was accuracy, as how many times students made mistake in speaking. These indicators were properly to the successful speaking activity. In Mora (2010) a successful speaking activity would be seem if the learner talks a lot, participant is even and motivation is high. The students talked a lot showed by the students' speaking duration where the students' had started to speak more in long duration.
Participant is even showed by the students' speaking where more than half of the students joint the activity. Motivation is high showed by a lot of students tried to speak in good accuracy even though they had mistake before

It answered the research question, how Think-Pair-Square-Share (TPSS) strategy can improve the students' speaking ability at XI language class of SMAN 4 Bengkulu. TPSS strategy answered the question through the implementation of TPSS to the students. By Thinking first the topic, it gave an opportunity to the students had critical thinking and self sufficient in solving the topic before go to the group discussion (pair and square). Thus, in Pair step, the students could practice to speak up with their partner. It also gave opportunity to the students in sharing and developing the ideas. While in Square step, the students had another chance to become cooperate for the best result, encouraged each other and got more practice in speaking. Finally, in Share was time to listen and respond the others ideas.

Through the four steps, the students' speaking ability, duration, frequency and accuracy could be improved. By implementing a group work gave them opportunity to practice to speak in pair and square. It encouraged them to speak to the whole class. The procedures of TPSS strategy also helped the students to speak more and more, so they had times to produce as much as many words. Then, by the four steps of procedures of TPSS strategy (think, pair, square and share), the students who did mistakes, could consult and ask their friend in pair or square, so that, the mistakes done before could be diminished.

After Pre test done, cycle 1 was applied. The teacher started to apply the new strategy in teaching and learning process. Based on the data finding, the students' speaking frequency, duration 
and accuracy were improved than pre test. Even though the result showed the improvement, but the students' attitude in the class was still low. They made noise, chatted with friends, shouted and went out of class. To overcome the problems, the teacher decided to conduct the next cycle.

In cycle 2 , based on the result, the teacher made a variation. Mulyadi and Puspita (2009) explained that a variation is to create an activity different from common activity. In order to solve the problems above, the teacher modified the way in delivering the material by using pictures. As Kayi (2006) explained that picture fosters the creativity and imagination of the learners as well as their public speaking skills. So, to overcome the problems in cycle 1 , pictures as a media in teaching and learning process had been applied. It was proven that the students' seemed more interested to the material and also they could develop the ideas more deep. Furthermore, the teacher also made a leader in every group in order to diminish noise, shouting and going out of class. The result observation finding showed through a leader in every group made them more focused on the topic.

On the end of the research, post test was conducted to see the students' improvement. The result finding not only showed the significant improvement in the students' speaking frequency, duration and accuracy but also the students' attitude. It meant the implementation Think-Pair-Square-Share strategy at XI Language class of SMAN CONCLUSION

Based on the results of the research that had been done at XI Language class of SMAN 4 Bengkulu, it can be conclude that:

Teaching speaking by using ThinkPair-Square-Share strategy is important both for the teacher and the students.
4 Bengkulu was success. Unfortunately, every meeting in this cycle was different. Not all of the students presented and follow the action. In first meeting, all of the students were present, but on the second and so on, two students were absent and miss the class. It could become one of the reasons why the result did not increase as much as expected.

This research also reflected to the previous study. There were some gaps or weaknesses of the previous study. First, the previous study did not provide enough assistance for the low achievers during the square session. So that was why the teacher made a team leader in every square. The duty of the leader was to control the square in discussion time in order to decrease shouting and chatting to others square. Second, the previous study also did not give time limitation during the sharing session, so the students were confused when to stop. To avoid this problem, the teacher gave limited time in every step of Think-Pair-Square-Share strategy. So, the students could be ready before going to the next step.

Finally, after the implement of the strategy, the result finding the improvement where a comfortable learning in which the reluctant, unconfident or shyness, not knowing to say, nervous in making mistakes were no longer bothered. Otherwise, the students felt comfort learning together with friend. Furthermore, in TPSS strategy classroom activities was succeed to improve the students' speaking ability; frequency, duration and accuracy.

Through this strategy, the English teacher can solve the speaking class problem effectively. By using this strategy, students have motivation to learn and involved actively in an interaction to explore their idea in order to win the games and attain good results. 
Think-Pair-Square-Share (TPSS) strategy helped students to reduce their reluctant and nervous since by pair works and square works students had responsibility to deliver information or ideas to others. The students' got opportunity in practice speaking more.

Furthermore the improvement was also showed through the students' frequency, duration, and accuracy percentages. Based on the percentage result in the previous chapter, there were 6 students spoke in long and medium parts in pre test, $42 \%$ students in cycle 1 become $79 \%$ or 15 students in cycle 2 and post test. For the students' duration, there were $47 \%$ students had long and medium duration in pre test, $58 \%$ students in cycle $1,79 \%$ students in cycle 2 , and $84 \%$ students in post test who spoke had long and medium duration in speaking class. For the improvement of students' speaking accuracy, the improvement could be seen from the difference of the percentages of students' speaking accuracy results. There were $37 \%$ students who spoke in good part in pre test, $69 \%$ students in cycle 1 who spoke in good and very good parts. Then there were $79 \%$ students in cycle 2 and post test who spoke in good and very good.

As conclusion, using Think-PairSquare-Share (TPSS) strategy was effective to improve students' speaking frequency, duration, and accuracy at XI Language class of SMAN 4 Bengkulu.

\section{REFERENCES}

Bygate, M. (1987). Speaking (Language Teaching: A scheme for Teacher Education). Oxford: Oxford University Press.

Castillo, C.Y.P. (2007). Improving Eleventh Graders' Oral Production in English Class through Cooperative Learning Strategies. Bogotá, Colombia. Thesis. p. 77-78.
Gay, L. R. (1990). Educational Research: Competencies for Analysis and Application, $3^{\text {rd }}$ Edition. Republic of Singapore: Merrill Publishing Company.

Handayani, R N. (2010). Improving Students' Speaking English in the Classroom Through the Use of Jigsaw at vii a SMPN 13 Kota Bengkulu. Bengkulu: Universitas Bengkulu. Unpublished Skripsi.

Hornby, A S. (2007). Oxford Advanced Learner's Dictionary of Current English, 7th edition. New York: Cambridge University Press.

Isnaini, M. H. 2011. Improving the SpeakingAbility of the Tenth Graders of SMK Negeri 1 Singosari Malang through Think-Pair-Square Strategy. Unpublished Skripsi. Malang: University of Malang. Abstract.

Istudy. (2012). Cooperative Learning. Journal internet, from http://tlt.its.edu/suggestions/teams/about/ benefits.html

Jolliffe, W. (2008). Cooperative Learning in The Classroom; Putting it into Practices. Great Britain: Cpod, Trowbridge, Wiltshire.

Kagan, S. (1992). Cooperative Learning. California: Resources for Teacher, Inc.

Kayi, H. (2006). Teaching Speaking: Activities to Promote Speaking in a Second Language. The Internet TESL Journal, Vol. XII, No. 11, retrieved November 2006 from http://iteslj.org/Articles/KayiTeachingSpeaking.html.

Koshinsky, E. (2008). How to Teach Speaking. Computer Assisted Language Learning, retrieved April 24 from http://teacherscall.com/2008/04/how-to-teachspeaking.html/trackback.

Mulyadi and Puspita, H. 2009. PengajaranTerbatas (Micro Teaching). Bengkulu: Universitas Bengkulu.

Mora, M. (2010). Teaching speaking. Medan: State University of Medan. 
Nunan, D. (2003). Practical English Language Teaching, $1^{\text {th }}$ ed. Singapore: McGrawHill Companies, Inc. p. 55.

PLNU. (2004). Think-Pair-Square-Share. Point Loma Nazarene University, from http://PLNU.com

Priyana, J., Machfutra, D., \&Zayin, A. M. (2008). Interlanguage: English for SMAN Students XI. Jakarta: PusatPerbukuan,DepartemenPendidikan Nasional.

Susanti, A. D. H. (2007). Using Role Play in Teaching Speaking (A Pre-Experimental Study at Islamic Junior High School SoebonoMantofaniJombang-Ciputat).

Yogyakarta: State Islamic University. Skripsi.

Wafi, A. (2011). Using the Think-Pair-SquareShare Strategy to Increase Students' Active Involvement and toImprove Students' Speaking Ability at Islamic the University of Malang. Unpublished Skripsi. Malang: University of Malang. Abstrac.

Wulandari, M, F. (2012). Improving students' speaking comprehension by usingexperience-text-relationship (ETR) Strategy (a Classroom Action Research at Grade VIIIA SMP Negeri 11 Kota Bengkulu). Unpublished Skripsi. Bengkulu: Universitas Bengkulu.

Zainil. (2010). Actional Functional Model (AFM): Classroom Action Research. Padang: Sukabina Offset. 